of the clinical thermometer is dealt with in an illuminating way, and the instruments of Hunter, Aitken and Allbutt are specially noteworthy.

The great medical classics of the period are shown in the section on clinical medicine, including the works of Addison and Bright. Also shown are some of the original series of coloured prints of pathological subjects made for Bright's great work. There is a fine commemorative plaque to Charcot, and some original apparatus used by Duchenne.

Space does not permit of further descriptions of individual items, but it may be said that the section on blood-letting will repay careful study, and that the section on blood-transfusion lays due emphasis on the work of Blundell and of Aveling. The exhibits dealing with infectious diseases include the pioneer works of Stewart, Murchison, Snow and others; and the section on public health exhibits a number of scarce prints illustrative of the hygienic conditions of the time.

This fine exhibition is full of interest and instruction for the scientific worker and layman alike, and the staff of the Museum are to be congratulated on the results. A full descriptive and bibliographical catalogue has just been published by the Oxford University Press*, and is obtainable at the Museum or from the Press.

* Catalogue of an Exhibition illustrating Medicine in 1850. Published for the Trustees of the Wellcome Historical Medical Museum. Pp. 64. (Oxford University Press, 1950.) 3s. net.

\section{RESEARCH IN THE UNIVERSITY OF BIRMINGHAM}

\section{ANNUAL REPORT FOR 1948-49}

$\mathrm{T}$ HE twentieth annual report of the Joint Standing Committee for Research of the University of Birmingham covers the session 1948-49*, and the summaries included under the departmental sections give a comprehensive survey of progress made in the various fields during the year. To these summaries are appended departmental lists of papers published during the year and of titles of theses approved for higher degrees. Only publications which can properly be regarded as contributions to original knowledge are included.

In the Department of Physics the most ambitious undertaking was the construction of a synchrotron for the acceleration of protons to energies corresponding to about 1,200,000 volts; good progress was made in this undertaking. The cyclotron was out of operation for alterations during much of the year. The research programme benefited greatly from the arrangements made for universities to obtain radioactive materials and electronic equipment from government sources. In the Department of Chemistry the balance of work between the physical and the organic side was much more even, much of the former being concerned with the chemistry of synthetic high-polymers and of the latter with the chemistry of natural high-polymers such as cellulose and starch. Work on synthetic high polymers comprised the investigation of the mechanism of synthesis with the view of putting the whole matter on a sound quantitative and absolute basis. Further researches were

* Uniyersity of Birmingham: Joint Standing Committee for Research. Twentieth Annual Report, Session 1948-49. Pp. 81. (Birmingham: The University, 1950.) carried out to elucidate the mechanism of heterogeneous processes such as the thermal decomposition of crystals of nickel formate, and work on the determination of molecular structure by X-ray diffraction continued, as well as on the new organic fluorine compounds. Help was given to the development of dextrose blood-plasma substitute, the group working on chemistry in relation to tuberculosis continued work on the separation of nucleic acid and carbohydrate components from cells which might have a preventive action against the disease, and a vigorous section was established for research on analytical chemistry.

Work continued in the Department of Zoology on the mechanism of transplantation immunity in animals, and further support for the hypothesis that certain virus-like cytoplasmic factors may be of endogenous origin was obtained from immunological and other studies on 'infective' agents responsible for natural skin coloration in mammals. A study of wound healing was commenced and work completed on the differential host preferences of the hymenopterous insect Cephalonomia. In the Department of Botany research on salt relations of plant cells indicated that the antagonism between ions in their absorption concerns both phases in absorption. Symptoms similar to those resulting from ion deficiency noted on land treated with sewage sludge contaminated with industrial waste were attributed to toxicity due to heavy metals, and the effects of cobalt, nickel, lead and manganese on the growth of tomatoes were investigated. Studies of the effect of soil conditions on the development of red-core disease of strawberries continued, while the Department of Genetics tested statistical methods devised for analysing continuous variation on the inheritance of flowering-time and plant-height in Nicotiana rustica. Investigations of the progress of inbreeding were started in Drosophila and rye.

The Department of Geology carried out work on natural and artificial glasses, with special reference to atomic packing, and considerable progress was reported in the design and construction of apparatus for work at temperatures up to $750^{\circ} \mathrm{C}$. and pressures of 1,000 atmospheres. In the Department of Mechanical Engineering research activities centred mainly on the investigation and application of the pressurewave phenomena which result from the sudden release of compressed gas, for example, from an engine cylinder, while in the Department of Civil Engineering two fundamental studies were made on the use of light alloys for large structures. Moment distribution methods for complex frames and space frames and the development of the beam-line method for solving problems on elastic and non-elastic frames were also studied. In the Department of Electrical Engineering several investigations on control systems, especially closed-sequence or servo-system type, were in progress, including contributions to theory, analysis and testing and the development of new devices. Earlier work on the mutual interference of radio waves in the ionosphere was being continued.

Research in the Department of Chemical Engineering was concerned mainly with liquid-vapour equilibria and their application to extractive distillation, combustion of hydrocarbons, chemical composition of coal tar, preparation and reactions of hydrocarbons and the diffusional factors concerned in mixing; also, work was started on pressure-volume-temperature relations of hydrocarbons under critical conditions, chemical compounds containing inorganic 
elements present in petroleum, the rate of evaporation of solvents from petrol soap gels and the products formed in the pre-flame combustion of fuels in the pressure-ignition engine. The School of Malting and Brewing and the Department of Industrial Fermentation were concerned mainly with the nutritional requirements of fermentation micro-organisms and the action of the amylases. The Department of Physical and Theoretical Metallurgy extended its work on the theory of the constitution of alloys and of the deformation of metals and alloys. The electrical properties of cold-worked iron during strain-ageing were examined, and the X-Ray Laboratory extended work on a technique for studying the structure of cold-worked metals and of martensite. The Department of Industrial Metallurgy inaugurated a programme of work on the non-homogeneous deformation of metals during rolling; and the welding of aluminium alloys, the nature and effect of hydrogen absorption on the properties of spring steels, and nucleation and its effect on the cast structure of alloys were also studied. Work in the Department of Mining covered the chemical constitution of coal, low-temperature atmospheric oxidation of coal, factors influencing the properties of suspensions of solids in fluids and froth flotation of chromite.

In the Faculty of Medicine, the research activities of the Department of Anatomy were concerned with the hormonal control of reproduction, experimental embryology, the inter-relation of hormonal and neural factors in physical and behavioural men. struation, studies of growth and body proportions, and analysis of cranial and dental characters of monkeys and apes. The Department of Physiology studied the factors concerned in the maximal rate of secretion of $p$-aminohippuric acid by the kidney, visual contrast, folic acid deficiency, the role of progesterone in the mechanisms of pelvic relaxation in the mouse, metabolism of sulphonamides and the constitution of blood-group substances. Numerous investigations in the Department of Bacteriology included the cytology of bacteria, chemotherapy of tuberculosis and actinobacillosis of cattle. The Department of Pharmacology and Therapeutics was engaged in research on the main factors which determine the rate and extent of lipolysis, emulsion systems for intravenous use, lipoprotein structure and the central nervous system, and devised a new method for testing substances with anthelmintic activity, using the liver fluke.

\section{NEW ZEALAND FOREST SERVICE ANNUAL REPORT FOR 1948-49}

$\mathrm{U}$ NDER the heading "Forest Policy" in the annusl report for the year ending March 1949 of the director of forestry of the New Zealand State Forest Service*, it is announced that the decision has been taken by the Government of New Zealand, after a quarter of a century of planning and research work, to establish a saw mill and a pulp and paper mill at Murupara, on the Rangitaiki River in the Rotorua Forest Conservancy-the first of its type in the Dominion. It is stated that only by the establishment of such a combination of saw mill and pulp and paper plant can exploitation of the enormous Kaingaroa

*New Zealand State Forest Service. Annual Report of the Director of Forestry for the Year ended 31st March, 1949. Pp. 86. (Wellington :
Government Printer, 1949.) 18. 9d.
State Forest, representing an expenditure of several million pounds, be justified. "It must be realized," says the director, "that as a saw-log development alone, the Kaingaroa State Forest could not very well be poorer, largely due to the trees having been planted too widely apart and left without any sylvicultural treatment in the interim." Therefore, the only way in which large saw-log production could be justified was by having an associated pulp and paper plant to absorb both the small-diameter and the rough knotty logs which cannot be converted into sawn timber at a profit.

References have been made in Nature during the past twenty years to the great conifer-planting schemes which were commenced during the closing years of the past century. The planting of conifers, of which Pinus insignis was the first chosen, was commenced by the Forest Department and afterwards taken up as a commercial proposition by private com. panies, the latter confining themselves almost entirely to the latter. Owing to the risks from pests and later the necessity of knowing the quality of the material being produced by this enormous area of artificially grown exotic conifers, research work was undertaken. "By 1928," says the report, "it had been proved, through the extensive tests both on the experimental scale at the famous Madison Forest Products Laboratory and on a commercial scale at the mills of the Consolidated Pulp and Paper Co. at Wisconsin Rapids, Wisconsin, that insignis pine and other exotic softwoods could be used for newsprint, kraft and other papers. Kaingaroa State Forest was extended to provide an ample supply of pulp-wood as well as of saw-logs, etc., and ever increasing proportions of species other than insignis pine were used for this purpose."

This State forest policy was thus in strong contrast to that of the forest companies, which concentrated largely on the planting of the insignis for pulp and paper production alone. The State Forest Service had taken as its model the Scandinavian policy, which had, of course, arisen from having at the start large areas of virgin forest as a basis to establish the utilization and exploitation policy, namely, that an economic pulp and paper industry is only practicable as a supplementary activity to the utilization of saw logs "which probably for all time will remain the most important and basic product of the forest". To this latter statement there are, of course, considerable reservations in other parts of the world.

The New Zealand State Forest Service owes its present position in this matter to the late Mr. William Adamson, the technical director of Walmsleys, Ltd., Bury, England, who visited the Dominion in 1925. After examining the existing coniferous areas, transport problems and so forth, he made certain recommendations, the most important of which was that no pulp and paper plant should be established until a unit of economic size, as judged by world standards, could be justified both by continuity of wood sup. plies and adequacy of demand. Small plants cannot be developed on an economic basis. Not only has Mr. Adamson been responsible for the supply of paper machines to many parts of the world, but he has also been associated with the designing and building of some of the most famous pulp and paper plants in the world, including the enormous Conerbrook operation of Bowaters, Ltd., in Newfoundland. His greatest monument will rest upon the work he did for New Zealand, upon which this conception of a forest policy is based. 